\title{
Textile wastewater treatment by anaerobic sludge blanket reactor
}

\author{
F. Khan, M. Waddadar and T. Ahmed* \\ Department of Civil Engineering, Bangladesh University of Engineering and Technology, Dhaka-1000, Bangladesh
}

Received: 28 October 2019

Revised: 05 November 2019

Accepted: 11 November 2019

DOI: $10.3329 /$ bjsir.v55i3.49389

\begin{abstract}
In this study, performance of a lab-scale hybrid up-flow anaerobic sludge blanket (HUASB) reactor treating textile wastewater was evaluated under several operating conditions such as i) textile wastewater mixed up with glucose as food, ii) textile wastewater seeded with sewage sludge and glucose and iii) textile wastewater only. In all cases, two days of incubation period was provided for bacterial growth. In the first case, Klebsiella was the primary Species of bacteria growing in the reactor and the removal efficiency of COD and color was $25 \%$ and $56.4 \%$ respectively. In the second case, Klebsiella and Escherichia coli were the major bacteria and removal efficiency of COD and color was found to be $38 \%$ and $65 \%$ respectively. In the last case, Pseudomonas bacterium was dominant in the reactor and removal efficiency of COD, BOD and color was $84 \%, 93 \%$, and $97 \%$ respectively. Wastewater treatment without glucose favored the growth of Pseudomonas which has been found to be effective in degrading organics present in textile wastewater. For all cases, reactor performance decreased after the third or fourth cycle of treatment. However, the removal of sludge after the third cycle allowed a high degradation efficiency of organics to be maintained in the reactor. With proper bacterial growth and maintenance, the HUASB reactor can be a huge upgrade from conventional UASB and a suitable alternative to conventional processes for the treatment of textile wastewater.
\end{abstract}

Keywords: Hybrid UASB; Textile wastewater treatment; Anaerobic process; Pseudomonas

\section{Introduction}

The textile industry contributes a significant portion of the total exports of Bangladesh. Share of ready-madegarments (RMG) in national export is $85.43 \%$ (BBS, 2017). However, the textile industry consumes large quantities of water and produces large volumes of wastewater. It is estimated that textile industries in Bangladesh generated around 217 million $\mathrm{m}^{3}$ of wastewater in 2016 and if the textile industries continue using conventional dyeing practices then wastewater production for the year 2021 will be 349 million $\mathrm{m}^{3}$ (Hossain et al., 2018). Wastewater from printing and dyeing units is often rich in color, contains residues of reactive dyes which are mostly aromatic and heterocyclic organic compounds, cotton, woolen, and synthetic fibers depending upon the used raw materials (Wang et al., 2011). The toxic effects of dyestuffs and other organic compounds, as well as acidic and alkaline contaminants, from industrial establishments on the general public are widely accepted. At present, the dyes are mainly aromatic and heterocyclic compounds, with color-display groups and polar groups. The structures of these compounds are complicated and stable which poses greater difficulty for degradation using conventional wastewater treatment processes (Joshi et al., 2004).

In the past several decades, many techniques have emerged to find an economical and efficient way to treat 
the textile dyeing wastewater, including physicochemical, biochemical, biological and combined treatment processes. Industries adopting chemical treatment processes are facing the problem of excessive sludge generation which is unmanageable in most developing countries (Samer, 2015). Also, chemically treated water with low regulation may pose an additional health hazard (e.g. formation of trihalomethanes) (Akpor, 2011). Aerobic treatment processes show lower efficiency under increased organic loading, have a high operational cost associated with blower operation and generates a large amount of sludge. These problems have led industry owners to adopt anaerobic wastewater treatment processes which could potentially overcome some of these problems. The Up-flow Anaerobic Sludge Blanket (UASB) Reactor has been successfully implemented to treat wastewater in our neighboring country, India for more than 20 years and its performance has been found to be satisfactory (Khalil et al., 2006). Presently over 200 full-scale UASB plants are in operation all over the world for the treatment of both domestic and industrial wastewaters.

UASB reactor is a methanogenic (methane-producing) digester. It has been found to treat wastewater containing high chemical oxygen demand (COD) and biochemical oxygen demand (BOD) when aerobic treatment becomes ineffective. The UASB reduces $\mathrm{COD}$ and $\mathrm{BOD}$ concentration to such a level that it can be treated further using aerobic processes. The main advantage of this technology is low capital cost, low energy requirements, low operational and maintenance costs (Miah, 2013). The treatment process consists of a combined process (anaerobic and bio-filtration process). No chemical is needed except for controlling $\mathrm{pH}$. Moreover, the biogas produced from the UASB reactor can be used to recover energy (Daud et al., 2018). But in this technology, a start-up period of 3-4 months is needed for granule formation in a delicately controlled environment (Hulshoff Pol et al., 2004). Besides, COD removal efficiency is about $50 \%$, necessitating further treatments (Amaral et al., 2014). If the environment for bacterial growth is disturbed, the reactor fails and an additional maturation period for granules is needed for restarting. In order to eliminate all these shortcomings, a modification has been proposed to the conventional UASB which is through the introduction of a media for attached growth and the modified setup is termed as hybrid UASB
(HUASB). This adjustment has been found to reduce the start-up time, enhance COD and color removal efficiency and to lower down retention time (Priya et al., 2015). As this technology works better in a hot climate, it is deemed to be highly suitable for countries like India and Bangladesh. The application of HUASB is yet to be done in large industrial effluent treatment plants in Bangladesh.

The objective of this study is to evaluate the performance of the HUASB reactor treating textile wastewater in Bangladesh. A lab-scale reactor was operated and bacterial growth, sludge production, COD, BOD and color removal efficiencies were monitored under different operating conditions over time.

\section{Materials and methods}

Textile wastewater from Mahmud Denims Limited, Shafipur, Kaliakoir, Gazipur was used in our experiments. This is a textile industry comprising spinning, weaving, dyeing and jeans section. The production capacity of the industry is about $1,50,000$ yards/day while consuming about $2500 \mathrm{~m}^{3}$ water/day. Water used for processing is mainly groundwater. The wastewater was fed with cow dung at a ratio of $1: 3 \mathrm{v} / \mathrm{v}$ in the feeding tank. Wastewater was collected in 251 airtight plastic containers from the equalization tank of the ETP of the industry. The raw wastewater characteristics are shown in Table I.

\section{Table I. Characteristics of raw wastewater}

\begin{tabular}{ll}
\hline Parameter & Value \\
\hline $\mathrm{pH}$ & 7.4 \\
Electrical conductivity (mS/cm) & 6.59 \\
Color (Pt-Co Unit) & $8700-8900$ \\
Dissolved oxygen (mg/l) & 0.06 \\
Phosphate (mg/l) & 72 \\
Total dissolved solids (mg/l) & 1578 \\
Total suspended solids (mg/l) & 8513 \\
COD (mg/l) & $2416-2310$ \\
\hline
\end{tabular}

A lab-scale reactor with a capacity of 12.31 was fabricated using a transparent acrylic fiber cylinder with a diameter of 3.5 inches, a height of 6.5 feet and a wall thickness of 0.5 inches. The reactor is divided into three zones-decomposition zone, transition zone, settling zone. A schematic diagram is shown in Fig. 1. 


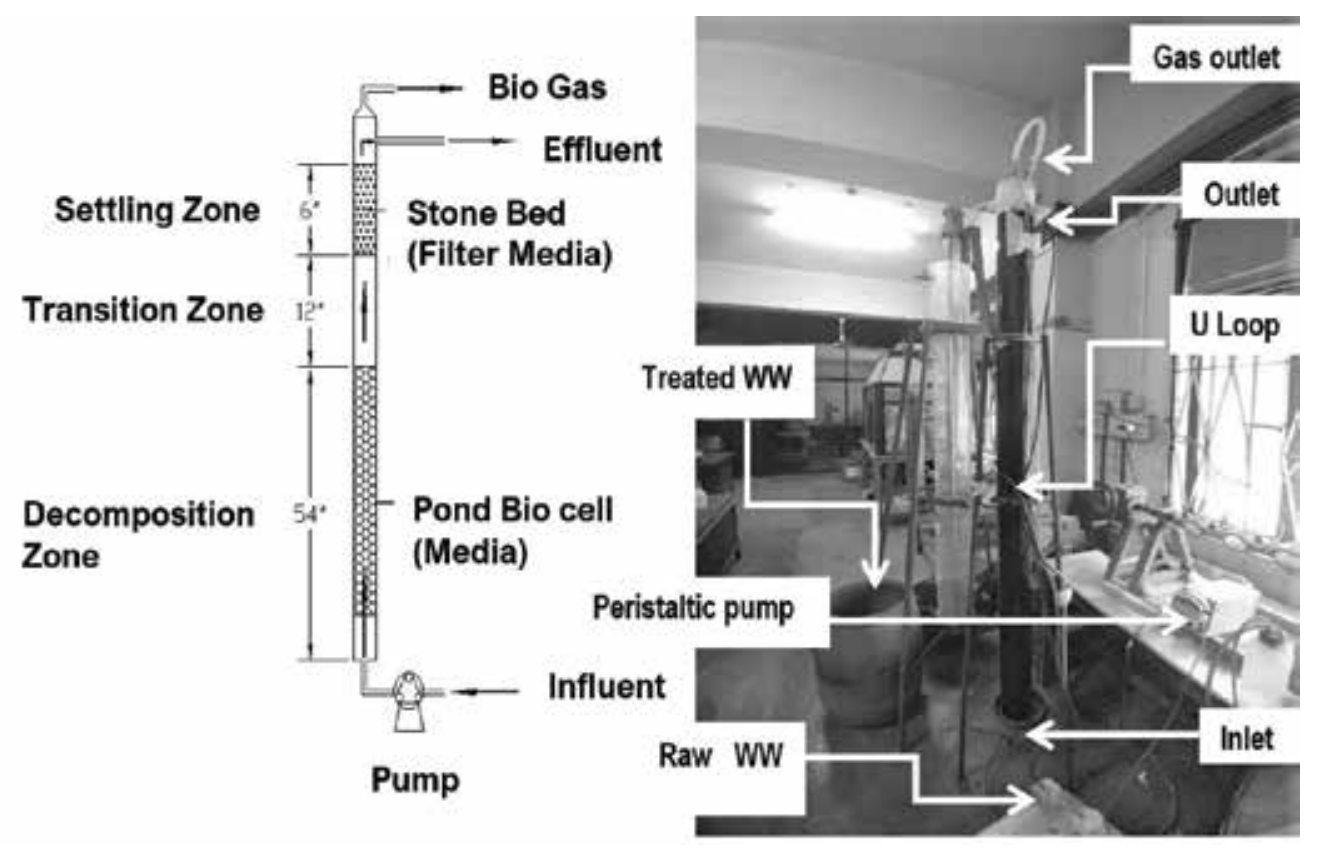

Fig. 1. Schematic diagram (left) and image (right) of the experimental setup

The decomposition zone was at the lower part of the reactor, 4.5 feet long and filled with pond bio cells (packing media, polypropylene rings of $20 \mathrm{~mm}$ diameter) in between two fixed screens $(0.2$-inch diameter screen size). The screens were placed 48 inches apart in the reactor. The lowest screen was placed 6 inches from the bottom of the reactor to facilitate sludge accumulation. Above the decomposition zone, there was a 1-foot blank space as a transition zone. The next 6-inch height was the settling zone filled with fine gravel (passing 3/8 inches sieve and retaining on \#4 sieve) held between two similar screens functioning as a filter media. Gravel bed and the packing media reduced the working volume of the reactor to $8.8 \mathrm{~L}$. Outlet pipe was connected to the effluent tank through rubber tubing with a U-loop. The U-loop provided a water seal and prevented the intrusion of atmospheric air into the reactor in order to retain anaerobic conditions in the reactor. A peristaltic pump was used to pump wastewater into the reactor.

Raw textile wastewater was treated with varying hydraulic retention times (HRT) under different start-up conditions. Five trials were given to treat wastewater using the laboratory setup. Anaerobic seed culture collected from the feeding tank of the ETP plant of Mahmud Denims Limited was used for the inoculation in the HUASB reactor. For the first trial, glucose was mixed with textile wastewater as a source of food for microorganisms. For the second and third trials, glucose and sewage sludge were added during start-up. For the fourth and fifth trials, only textile wastewater was fed in the reactor. An
HRT of 2 days was maintained during the reactor set-up period. 5-6 cycles of wastewater treatment were completed in each trial. Since the hydraulic characteristics of the reactor were closer to plug flow, samples at the inlet were compared with samples taken from the outlet one HRT later. Different parameters such as BOD, COD, color, electrical conductivity (EC), $\mathrm{pH}$, dissolved oxygen (DO), oxidation reduction potential (ORP), etc. were tested for each condition. Color was measured using a spectrophotometer (HACH DR2010) while electrode-sensor based meters were used to determine other parameters (pH: HACH HQ11d, EC: WTW multiline P4, DO:WTW oxi330, ORP: Hanna HI 98201). COD and BOD tests were carried out following Standard Methods (APHA, 2012). DO concentration less than $0.1 \mathrm{mg} / \mathrm{l}$ and ORP value less than $-300 \mathrm{mV}$ ensured anaerobic condition in the reactor. Bacterial growth was identified whenever there was a significant change in results. The reactor was operated at mesophilic temperature $\left(27 \pm 5^{\circ} \mathrm{C}\right)$. During winter the temperature was controlled by incorporating a room heater beside the reactor. The $\mathrm{pH}$ of the incoming wastewater into the reactor was maintained at 8 for optimal bacterial growth. Effluent $\mathrm{pH}$ varied between 5.6 7.5 which indicated that decomposition was taking place in the rector. For the first three trials, the reactor was operated for 5 to 6 cycles without desludging. For the fourth trial, sludge was fully removed after the fourth cycle. Whereas for the fifth trial, sludge was partially removed after the third cycle. For the detection of bacteria, water and sludge samples were taken from the reactor and sent to the pathology lab of Impulse Hospital, Dhaka, Bangladesh. 


\section{Results and discussion}

\section{Bacterial species}

Three types of bacteria were found in the reactor. In the first trial when glucose was added with wastewater, Klebsiella was the dominant bacteria. But the addition of sewage sludge in trials 2 and 3 introduced Escherichia coli along with Klebsiella. Exclusion of both glucose and sewage water in trials 4 and 5 initiated the growth of Pseudomonas. All these bacteria are gram-negative and facultative anaerobic. As all parameters inside the reactor were kept constant except the food for the microorganisms, the dominance of a certain species inside the reactor would be governed by the type of food present. The addition of glucose favored the growth of Klebsiella and since $E$. coli was present in sewage wastewater, the trials having both glucose and sewage added have both Klebsiella and E. coli. But when no glucose or sewage sludge was added, Pseudomonas was the dominant species in the reactor. Pseudomonas has been shown previously to grow in similar environments due to its greater capability in digesting complex compounds such as polycyclic aromatic hydrocarbons (PAH) (Karimi et al., 2015). Influent characteristics and corresponding dominant microbes are shown in Table II. improve the removal efficiency of the reactor. COD removal efficiency remained close to $43.0 \%$ for the first three cycles. However, it drastically decreases to $19.0 \%$ and $10.3 \%$ in the fourth and fifth cycles respectively.

Textile wastewater used as influent in this study had a high color value (8700 8900 Pt-Co Unit). For the first three trials, color removal performance were $56.4 \%, 65.0 \%$ and $20.6 \%$ which were not satisfactory. So, the color value of the effluent was not measured for every cycle. The color removal efficiency increased significantly from the fourth trial. Influent and effluent color and color removal efficiency for the last two trials are shown in Fig. 4 and 5 respectively.

For the first three trials, COD removal efficiency started to decrease from the fourth cycle (Figure 3). In these trials, the generated sludge remained in the reactor which could be affecting the performance of the reactor. So, in the fourth and the fifth trials, sludge was removed after the third cycle of wastewater treatment. In these trials, Pseudomonas was dominant in the reactor. Though HRT was comparatively lower compared to the previous trials $(\sim 7 \mathrm{~h})$, high COD and color removal were observed. COD removal for the first two cycles remained around 58\% which decreased to $27.3 \%$ in the third cycle. Color removal for the first two

Table II. Description of the trials and the dominant microbes in each trial

\begin{tabular}{lcc}
\hline \multicolumn{1}{c}{ Influent } & Klebsiella & E. coli \\
\hline Textile wastewater + Glucose, HRT 6 h (Trial 1) & $\checkmark$ & $\checkmark$ \\
Textile wastewater + Sewage sludge + Glucose, HRT 8 h (Trial 2) & $\checkmark$ & $\checkmark$ \\
Textile Wastewater + Sewage sludge + Glucose, HRT 24 h (Trial 3) & $\checkmark$ & $\checkmark$ \\
Textile wastewater, no additional food, HRT 7 h (Trial 4) & & $\checkmark$ \\
Textile wastewater, no additional food, HRT 4 h (Trial 5) & & \\
\hline
\end{tabular}

\section{COD and color removal}

In these experiments, the influent wastewater had high COD value $(2046 \mathrm{mg} / 1 \sim 3252 \mathrm{mg} / \mathrm{l})$. Influent and effluent COD and COD removal efficiency for different trials are shown in Fig. 2 and 3 respectively. For the first trial, COD removal efficiency gradually decreased from $33.8 \%$ to $11.6 \%$ from cycle 1 to 4 with the efficiency slightly increasing in the fifth cycle. The average COD removal efficiency is $25 \%$. An HRT of $6 \mathrm{~h}$ was maintained for all cycles and Klebsiella was identified in the reactor in this trial. In the second trial, HRT was $8 \mathrm{~h}$ and bacteria in the reactor were mainly Klebsiella and $E$. coli. COD removal efficiency gradually increases from $26.7 \%$ to $54.5 \%$ from cycle 1 to 3 and decreased to $34.3 \%$ in the fourth cycle. The average COD removal efficiency was $38.0 \%$ which was slightly higher than the first trial. Increasing HRT from 8 to $24 \mathrm{~h}$ in the third trial did not cycles remained around $96 \%$ which decreased to $60.7 \%$ in the third cycle. Removing the sludge after the third cycle resulted in $83.8 \%$ and $79.6 \%$ COD removal and $96.5 \%$ and $95.8 \%$ color removal for cycles 4 and 5 respectively. Further decreasing HRT from 7 to $4 \mathrm{~h}$ in the fifth trial did not affect the performance of the reactor significantly. In trial 5, initially, $86.9 \%$ COD removal and $97.6 \%$ color removal were observed in cycle 1 . Similar to trial 4, removal efficiency decreased in the third cycle $(32.1 \%$ for COD and $44.9 \%$ for color). After removing the sludge, the efficiency of the reactor increased to $76.6 \%$ and $87.3 \%$ for COD removal and $93.9 \%$ and $96 \%$ for color removal in cycles 4 and 5 respectively. It can be inferred that the accumulation of sludge had a negative impact on the performance of the reactor. For our setup, removing sludge after every three cycles increased the performance of the reactor. 
Trial 1

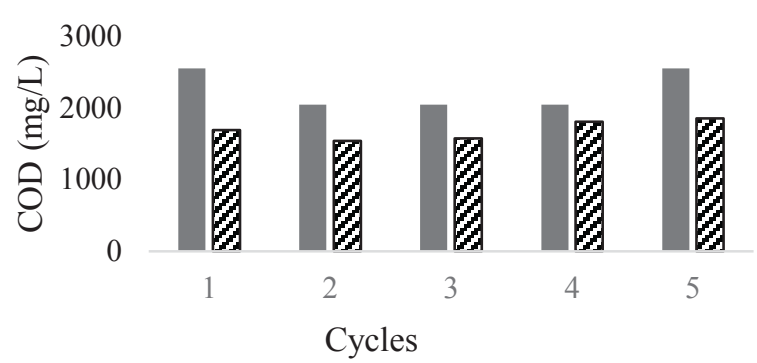

Trial 3

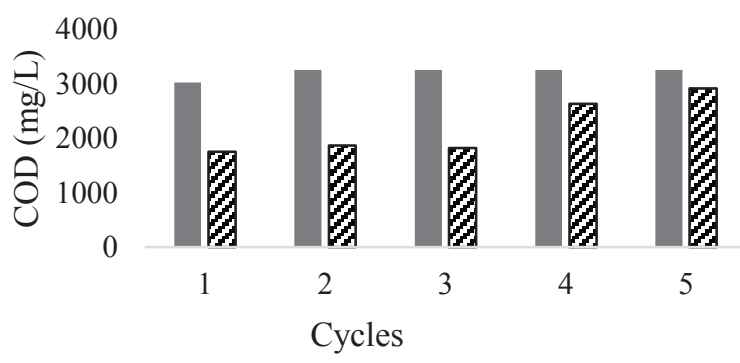

Trial 5

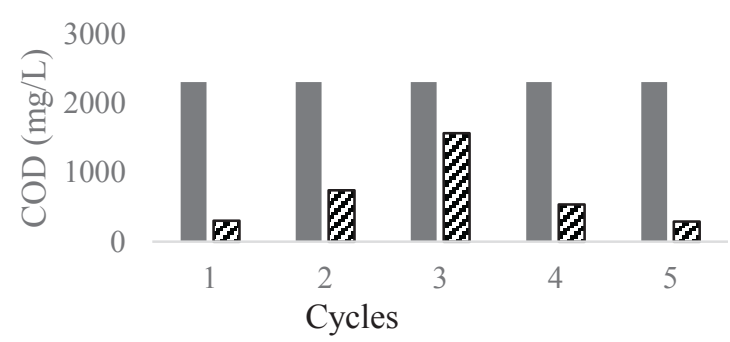

Trial 2

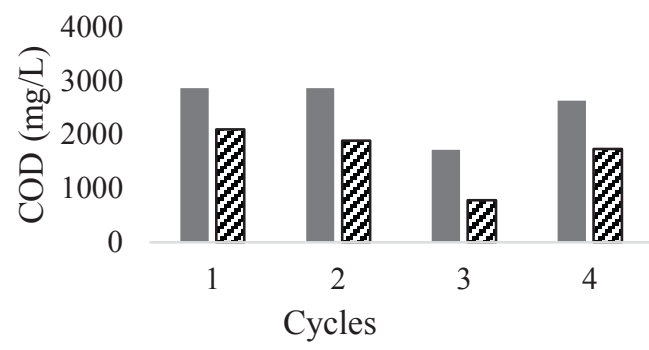

Trial 4

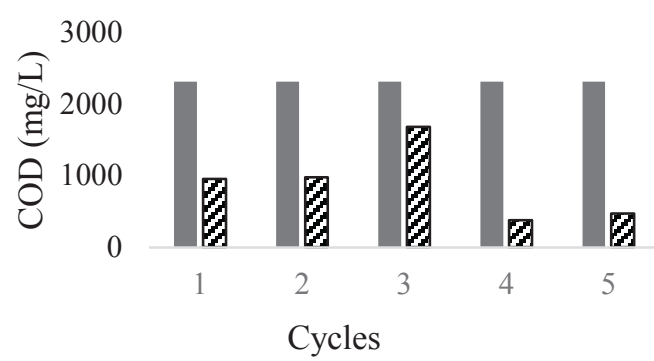

Fig. 2. Performance of the reactor in removing COD over different cycles of run for different trials where each trial represents different operating conditions

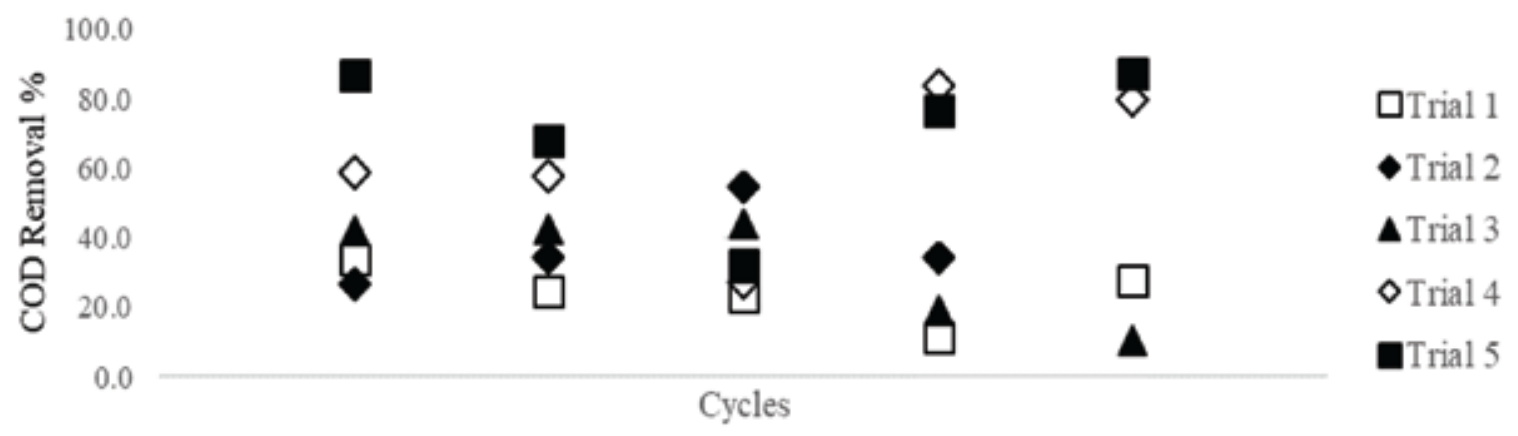

Fig. 3. COD removal efficiency for different trials 
Trial 4

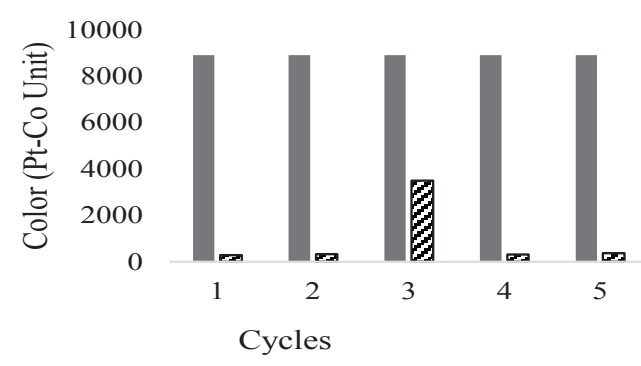

Trial 5

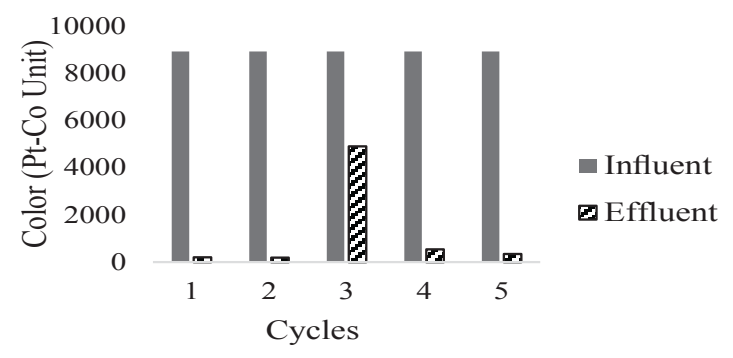

Fig. 4. Performance of the reactor in removing color over different cycles of run for different trials where each trial represents different operating conditions

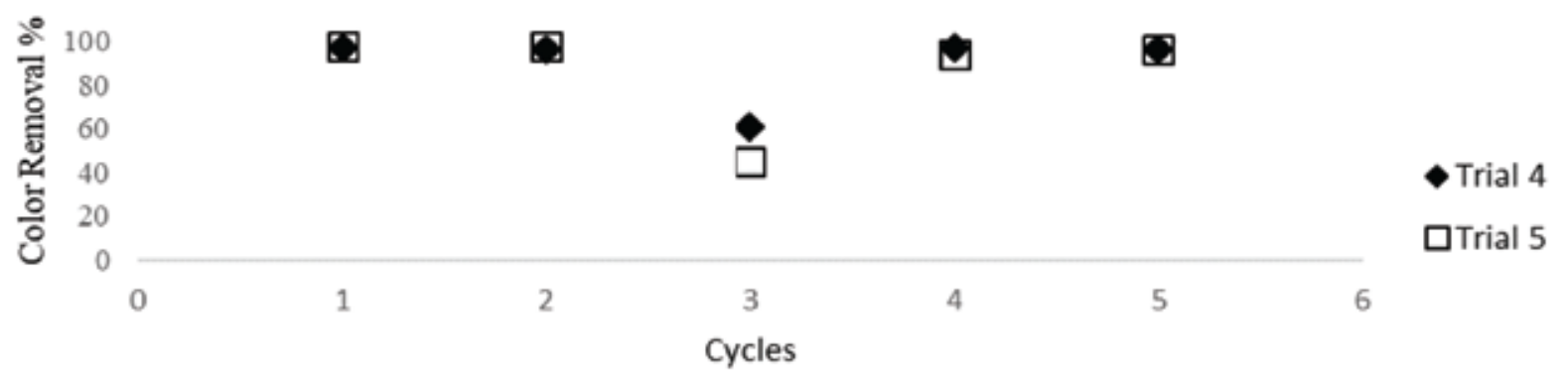

Fig. 5. Color removal efficiency for different trials

It has been mentioned earlier that different bacterial species were found in the reactor depending on the type of food present. The presence of these species can also be correlated with the removal efficiency obtained in the different trials (Fig. 6). It can be seen that while Klebsiella and $E$. coli were the dominant species in the reactor (trials $1-3)$, the COD removal efficiency did not exceed $54.5 \%$. Though sludge removal improves the efficiency of the reactor and sludge was not removed in trials 1 to 3 , it can be envisaged that even with sludge removal we would not

$$
\text { COD } \Delta \text { Color }
$$

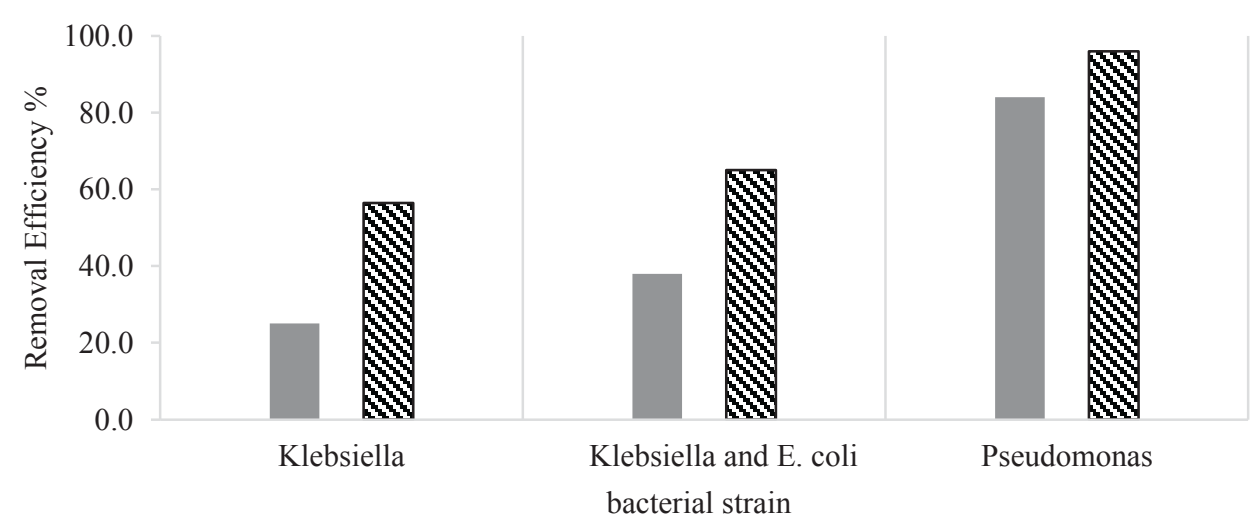

Fig. 6. COD and color removal efficiency for different bacterial growths 
expect the removal efficiency to go beyond what we observed in the initial cycles of these trials. On the other hand, in trials 4 and 5, Pseudomonas was dominant and due to its efficiency in degrading complex hydrocarbons, we observed higher COD and color removal compared to the previous trials.

\section{BOD removal}

As COD was the main parameter for evaluating the performance of the reactor, BOD was not monitored until significant removal of COD was achieved. Only after achieving more than $80 \%$ COD removal, BOD removal was measured. BOD value decreased from $730 \mathrm{mg} / 1$ to $52 \mathrm{mg} / 1$ and $54 \mathrm{mg} / \mathrm{l}$ in the fourth and the fifth trial respectively (removal efficiency 93\%, not shown in figure) which are well below the national discharge standard for BOD of textile industry effluent $(150 \mathrm{mg} / \mathrm{l})$ according to the Environment Conservation Rules (ECR) 1997.

\section{Comparison with full-scale UASB ETPS operational in} Bangladesh

The performance of the lab-scale HUASB was compared to three other UASB based full-scale ETPs currently operational in Bangladesh (Table III). These ETPs have Downflow Hanging Sponge (DHS) unit and aeration processes in addition to UASB unit and high retention time (40 h HRT for UASB unit). Though the final effluent quality conforms to the discharge limits described in the ECR 1997, the efficiency of the UASB unit in particular in the removal of COD, BOD and color is poor. ETP1 showed the best performance among the operational UASB units where a maximum removal of $66 \%, 53 \%$, and $50 \%$ for COD, BOD, and color respectively was obtained. ETP2 and ETP3 had comparatively stronger wastewater having influent COD values of 1075 and $2310 \mathrm{mg} / \mathrm{l}$ respectively. However, the removal efficiencies of these two ETPs are considerably lower compared to ETP1. For example, for ETP3, the wastewater from feeding tank is passed through two UASB reactors, each of which had an HRT of $20 \mathrm{~h}$ and in spite of having longer retention time than what we used in our experiments, $\mathrm{COD}, \mathrm{BOD}$ and color removals are $2.8 \%$, $18.0 \%$, and $3.0 \%$ respectively. Such low removal efficiencies are very unlikely for a UASB unit. Most probably, the accumulation of sludge is the reason behind the poor performance of the reactor. The UASB unit has been operational for more than a year. But according to the maintenance engineer, the sludge was never removed from the UASB unit which could have reduced the effectiveness of the process. In contrast, the DHS unit of that particular ETP performed better with a removal efficiency of $51 \%, 68 \%$, and $24 \%$ for COD, BOD, and color respectively. Our lab-scale HUASB reactor showed better performance than the UASB units of these ETPs. Moreover, in spite of having significantly lower retention time and no additional treatment operation (e.g. aeration), the lab-scale HUASB delivered an end product that was comparable to that of the three ETPs. This indicates that if a hybrid UASB can be installed in these

Table III. Comparison among operational efficiencies of different operational UASB based ETPs in Bangladesh and Lab-scale HUASB (Removal percentages with respect to the concentration in the equalization tank are shown in parentheses

\begin{tabular}{llcccc}
\hline ETP & Parameter & Equalization Tank & After UASB & After DHS & Outlet \\
\hline ETP 1(Rashid and Shahid, 2017) & Color (Pt-Co Unit) & 1264 & $432(66 \%)$ & $120(90 \%)$ & $110(91 \%)$ \\
UASB+DHS +Aeration & COD (mg/l) & 428 & $198(53 \%)$ & $179(58 \%)$ & $57(87 \%)$ \\
& BOD (mg/l) & 200 & $99(50 \%)$ & $69(65 \%)$ & $22(69 \%)$ \\
ETP 2 & Color (Pt-Co Unit) & 1320 & $1100(17 \%)$ & $1400(-6 \%)$ & $660(50 \%)$ \\
UASB+DHS +Aeration & COD (mg/l) & 1075 & $923(14 \%)$ & $658(39 \%)$ & $158(85 \%)$ \\
& BOD (mg/l) & 496 & $262(47 \%)$ & $160(68 \%)$ & $20(96 \%)$ \\
ETP 3 & Color (Pt-Co Unit) & 8900 & $8600(3 \%)$ & $6800(24 \%)$ & $23(99 \%)$ \\
UASB+DHS+ Aeration & COD (mg/l) & 2310 & $2246(3 \%)$ & $1124(51 \%)$ & $76(97 \%)$ \\
& BOD (mg/l) & 733 & $600(18 \%)$ & $233(68 \%)$ & $22(97 \%)$ \\
This Study (Lab-scale HUASB) & Color (Pt-Co Unit) & 8900 & $344(96 \%)$ & - & - \\
& COD (mg/l) & 2310 & $293(87 \%)$ & - & - \\
& BOD (mg/l) & 733 & $52(93 \%)$ & - & - \\
\hline
\end{tabular}


ETPs, their efficiencies can be increased with concomitant savings in operational costs.

\section{Conclusion}

UASB reactor generally requires post-treatment for satisfactory effluent quality. It takes almost three to four months for the growth of bacteria granules in UASB when no inert materials are added (Hulshoff Pol et al., 2004). But in hybrid UASB, bacterial biofilm is generated quickly because of the attached growth. For our lab-scale reactor, only two days were needed for the incubation of bacteria. Effectiveness of different bacteria grown in the reactor was evaluated and Pseudomonas was found out to be very effective which takes polycyclic aromatic hydrocarbon $(\mathrm{PAH})$ as the main food. After the growth of this bacterium in the reactor, removal efficiency of $\mathrm{COD}, \mathrm{BOD}$ and color increased significantly. After sludge was taken out, the reactor performance increased. Without further treatment, effluent quality from HUASB, particularly BOD and COD, has been found to conform to the limits for discharging in public sewerage system or irrigated land as prescribed in the national standards. So, with effective bacterial growth and maintenance, the HUASB reactor can be a huge upgrade from conventional UASB and a suitable alternative for the treatment of textile wastewater.

\section{Acknowledgment}

The authors would like to acknowledge Professor Dr. Farooque Ahmed for his comments and suggestions during the research and the staff of the Environmental Engineering Laboratory of BUET for their cooperation and assistance. Appreciation additionally goes to Mahmud Denims Ltd. for allowing us to their facility to sample their ETP wastewater for experiment.

\section{References}

Akpor OB (2011), Wastewater Effluent Discharge : Effects and Treatment Processes, Proc. $3^{\text {rd }}$ Int. Conf. Chem. Biol. Environ. Eng. pp 85-91,

Amaral FM, Kato MT, Florêncio L and Gavazza S (2014), Color, organic matter and sulfate removal from textile effluents by anaerobic and aerobic processes, Bioresour Technol 163: 364-369.

APHA (2012), Standard Methods for the Examination of Water and Wastewater, 22 ${ }^{\text {nd }}$ Ed. America Public Health Association, Washington, DC, USA,

BBS (Bangladesh Bureau of Statistics) (2017), Statistics and Informatics Division (SID), Ministry of Planning.
Daud MK, Rizvi H, Akram MF, Ali S, Rizwan M, Nafees M and Jin ZS (2018), Review of upflow anaerobic sludge blanket reactor technology: Effect of different parameters and developments for domestic wastewater treatment, $J$ Chem., pp 1-13. DOI: 10.1155/ 2018/1596319

Hossain L, Sarker SK and Khan MS (2018), Evaluation of present and future wastewater impacts of textile dyeing industries in Bangladesh, Environ Dev. 26: 23-33.

Hulshoff Pol LW, De Castro Lopes SI, Lettinga G and Lens PNL (2004), Anaerobic sludge granulation, Water Res 38: 1376-1389. DOI: 10.1016/j.watres.2003.12.002

Joshi M, Bansal R and Purwar R (2004), Color Removal From Textile Effluents, Indian J Fibre Text Res 29: 239-259.

Karimi B, Habibi M and Esvand M (2015), Biodegradation of naphthalene using Pseudomonas aeruginosa by up flow anoxic--aerobic continuous flow combined bioreactor, J Environ Heal Sci Eng. 13: 26.

Khalil N, Mittal AK, Raghav AK and Rajeev S (2006), UASB Technology for Sewage Treatment in India: 20 Years Experience, Environ Eng Manag J. 5: 1059-1069.

Miah MS (2013), Cost-effective Treatment Technology on Textile Industrial Wastewater in Bangladesh, J Chem Eng. 27: 32-36. DOI: 10.3329/jce.v27i1.15855

Priya M, Meenambal T, Balasubramanian N and Perumal B (2015), Comparative Study of Treatment of Sago Wastewater using HUASB Reactor in the Presence and Absence of Effective Microorganisms, Procedia Earth Planet Sci. 11: 483-490. DOI:10.1016/ j.proeps.2015.06.048

Rashid I and Shahid SB (2017), Evaluation of Up-flow Anaerobic Sludge Blanket (UASB) Treatment Process in Treating Textile Wastewater, B.Sc. Thesis, Bangladesh University of Engineering and Technology, Dhaka, Bangladesh. DOI: 10.2166/ wst.2006.794

Samer M (2015), Biological and Chemical Wastewater Treatment Processes. Wastewater Treatment Engineering, $1^{\text {st }}$ Ed. (In Tech Europe) p 3.

Wang Z, Xue M, Huang K and Liu Z (2011), Textile Dyeing Wastewater Treatment In: Advances in Treating Textile Effluent, Ed. Hauser P (In Tech) p 91. 